\title{
Modern terrorism between US and Israeli targets and the weakening of the Arab world
}

\author{
Younes Al-Jamra \\ Assistant Professor Faculty of Law and Political Science \\ Jadara University Irbid / Jordan
}

\begin{abstract}
The purpose of this study is to illustrate the phenomenon of modern terrorism between American and Israeli objectives and to weaken the Arab world. And the study focused on the central question: "How does America and Israel seek to weaken the Arab world through modern terrorism? ",This study answered the main question and the questions came out of it , and in this study we used analytical descriptive method ,therefore we got several conclusions, and the important of these are, First, there is no clear and limitdefinition for terrorism, second, America and Israel used terrorism to achieve objectives in the region, Third, leave the region in permanent conflict to reach weakness state.
\end{abstract}

Key words : Modern terrorism ,USA and Israeli targets , Weakening Arab world

\section{Introduction :}

The ancient and modern empires used the evil side of humanity to achieve their purposes without giving reasons, on the grounds that they protect humanity from the injustice of terrorism and the aggression against individuals, peoples and nations and their interests. While these major powers sought to achieve their political and economic objectives and expand their geographical influence, In the history we see the extent of the expansion of various empires, especially in the ancient world, which is today considered the Arab world is part of it . If we look at ancient empires such as: Romanian, Byzantine, Greek and Persian, we know why they occupied this part The ancient world.

Terrorism exists in the past and in the present among individuals, groups and countries, but there are also those who help in its development and use it as one of its tools in achieving its interests. Therefore, we find those who support it with money and weapons. These are either individuals, groups or countries because they seek to achieve their goals. And many of these groups, individuals or countries have been cared for with money and weapons and strengthened until the goal of the sponsor is achieved. These groups grow up and the first differences are with those who care for them. We have many examples, For example: Alqauda, its goal was ideological and the United States its goal economically and militarily, which encouraged the establishment and support for jihad against the Soviet Union, which occupied Afghanistan, the days of the Cold War to prevent the arrival of Soviet Union to the oil tank and the survival of America alone.

Thus, the United States and its allies were able to achieve their goals through this terrorist group, and then abandoned them. The clash began with terrorist acts outside the United States, such as the destruction of their embassies in Nairobi and Dar es Salaam in 1998, until September 11, 2001, The United States took advantage of this terrorism in its interest in occupying Afghanistan in November of that year, then began to prepare for the occupation of Iraq and the overthrow of its territory and the demobilization of its army to enter chaos in 2003. This was clear because the Saddam regime hit Israel thirty-nine missiles in through the process of desert storm 1991 after occupied Kuwait 1990, which means that the protection of Israel was one of its objectives in the region behind the accusation of Iraq embrace to terrorism. Thus the region fell into the arms of terrorism. 


\section{The importance of study :}

There are two importance of this study one is the importance of scientific: This stems from the importance of providing the necessary information on the phenomenon of terrorism, in order to be present in the minds of researchers from Arabs, Muslims and others, and this may be a cognitive increase when talking about this phenomenon, The others is practical importance stems from the phenomenon of terrorism and the joint American-Israeli objectives, the causes of this phenomenon and its motives, in order to enable specialists and decision-makers to develop plans that fail this phenomenon.

\section{The study Problem :}

The problem of the study lies in the statement of : Modern terrorism between American and Israeli objectives in weakening the Arab world. The problem of the study was expressed in the following central question: "How does America and Israel seek to weaken the Arab world through modern terrorism?", And branching from this question the following sub-questions:

1: What are the American and Israeli objectives in the Arab region?.

2: How is modern terrorism used to achieve US and Israeli objectives?

3: What are the means used by America and Israel to weaken the Arab region? .

\section{Objectives of the study :}

This study aims to achieve the following objectives:

1: Statement of American-Israeli objectives in the Arab region.

2: To highlight the employment of modern terrorism to achieve American-Israeli goals.

3: Identify the means used by America and Israel to weaken the Arab region.

\section{Methodology of the study:}

In this study, we used the analytical descriptive method: This method helps to determine the characteristics of the phenomenon to be studied and to determine its general form by collecting, categorizing and categorizing the information to reach the accurate facts, analyzing the causes and motives of reality or the factors influencing it, Analysis of documents and community studies and general trends, in order to answer the central question and the questions that branching from it, to achieve the objectives of this study as it should.

\section{Previous studies :}

There are many previous and important studies on terrorism, and we thought that we take from them to meet the need of this study to see what it said:

- In a study by the researcher "Gregor Bruce,2013" entitled: "Definition of Terrorism Social and Political Effects", The researcher believes that researchers and academic students to study terrorism should have the intellectual discipline to be able to focus on a specific subject. This facilitates communication between researchers and community organizations to provide the necessary measures to combat terrorism. Researchers believe that this phenomenon is a mixture of violence and politics, sociology and psychology, And that the threat includes actual violence and violence. The study concluded that a group of individuals and groups have a vested interest in terrorism and know the term terrorism by their bias, and that coalitions of nations, researchers, academics, professionals and governments want to protect their citizens. The media plays an important role in this aspect Social and political importance .

- The study of "Wa'am Mahmud al-Najjar,2012" entitled "The Political Recruitment of Terrorism in American Foreign Policy after September 11, 2001, and the Study of an Unpublished Master Thesis Examining the Time Period of George W. Bush's Judgment, Political, military and economic. The researcher adopted the historical method and analytical descriptive approach in his study. He reached the following important conclusions: The United States took advantage of the events of September 11 to achieve its interests. The United States also sought to draw new maps for the Middle East. 
This study differs from previous studies because it covered aspects not covered by these studies. There are also differences that have not been addressed, such as the importance of the Arab world as goal, and the American-Israeli goals that the two countries seek to achieve.

\section{1 :Terrorism: Concept and its contemporary history :}

\section{1:1 : Concept of terrorism :}

The term of terrorism is old since centuries ,it is a theological term mentioned in the Old and New Testaments, and it is rare to find it alone without the source of God or one of the apostles, kings or righteous fathers. In the Holy Qur'an, the word horror is equivalent to terrorism. and the Arab Gospels preferred to translate terrorism into fear,( Awwad, Hani,2015) and hence the concept of terrorism is vague, as it is known according to the situation and according to tendencies and attitudes, there are many definitions of the concept and the confusion between the resistance of the people to the occupation and the real terrorism, and therefore no one can say that this is the right definition or the definition contained in Article I The Geneva Convention of 1937, which defines terrorism as "criminal acts against a State, is intended to cause panic and horror among groups of people or individuals " (Geneva Convention of 1937 ,Article1). Here the definition does not mention state terrorism and to a people who resist those who occupy their land by force, as well as the practices of the great Powers against small States.

Thus, many researchers have presented a set of definitions of terrorism. In his book Political Terrorism, scholar Alex Schmid objected to it as abstract theoretical concepts that were not defined and shared many factors. Brian Genghis defines terrorism as "a set of acts intended to bring terror and fear." Terrorism "is the threat of extraordinary violence to achieve political objectives and to achieve psychological impact."( Abdol Haleem, Amera ,2009) The definition of the political dictionary "an attempt to spread panic and horror for political purposes and terrorism is a means used by an authoritarian government to force people to surrender to it"( Attia ,Ahmad , 1968, P.45), Encyclopedia of social science defines terrorism as "A deliberate attempt to terrorize the population by frightening means, either by the state or by a party aimed at overthrowing the state."( Hawari, Adel \& Mosleh, Saad ,1999,P.579 : Gregor Bruce , 2013 ,P.27) Walter Laqueur defines terrorism as "the illegitimate use of force to achieve a political objective by targeting innocent people"( Walter, Laqueur, 1977 ), And therefore we see that these definitions of terrorism as a whole share basic points such as: political objectives, terror, the threat of violence, the authoritarian government, the spread of panic and panic among people, illegal use and frightening means .Except resisting the occupier.

But our definition of terrorism is that "all attempts to intimidate and spread terror among innocents, rob them of their property and honor, and try to kill them on an ethnic, religious, sectarian, political or dissenting basis by any means, whether by individuals, groups, organizations or States, and excludes from this any form of resistance to those who occupy the land of others by force " .

\section{1:2: Contemporary history of terrorism :}

Regardless of the roots of terrorism, where did they come from?, the States and informal bodies have used the weapon of fear for a long time, and the use of fear may have its own system and dynamics. One wonders if this dynamic is developed or has cycles or changes in the social order?, may be These changes have brought some beliefs and events in the incidence of non-State terrorism.

David Rapoport has identified four major waves of international terrorism in his work on the history of international terrorism. First: anarchism "is a political philosophy that considers the state undesirable and not important, and is harmful to society. in return, it promotes a society without state, and seeks to limit the state or abolition of power intervention in the conduct of human relation "(Wikipedia.org, 2019), The peak of the first wave reached 1890 and continued until 1940. This period can be considered the golden age of assassinations. Every eighteen months president of state or a minister was assassinated ( Joel, Shurkin ,1998 )the period that saw the first international response to terrorism worldwide after the assassination of US President William McKinley in 1901, but the attempt to counter terrorism failed because of disagreement on a common view(David ,Rapoport, 2004).

The second wave: "Combating colonialism" began with the signing of the Treaty of Versailles ending the First World War. The principle of self-determination, used to dismantle defeated empires, shows a new type of terrorist organization, for example, the Irish Republican Army and various Jewish organizations operating against British forces in Palestine. The second wave of terrorist attacks mainly took place in the territories, 
which were caused by political problems of the withdrawal of the colonial forces in Palestine, where Menachem Begin, leader of the Jewish organization Ergun from 1943-1948, was allowed to carry out terrorist operations against Britain, described its members for the first time as freedom fighter(David, Rapoport, 2004), This is an inaccurate description of the fact, Britain gave the Balfour Declaration to establish a national homeland for the Jews in Palestine, gave them weapons and deprived the Palestinians the owners of land from weapons . and different organizations used terrorism against the indigenous people for their expulsion from their land under the auspices of Britain. And they did terrorism against the Palestinians and terrorizing them in order to evacuate the land for them.

The third wave was called the new leftist wave, which was the result of the Vietnam War. This period witnessed the assassinations and hijacking of 700 hijackers and hostages of 951 hostages from 1968/1982. This wave was similar to the first wave. Terrorism after the occupation of Palestine in full, as it was seeking to liberate its country from the Israeli occupation, the goals were mostly Israeli targets, and other American (David, Rapoport, 2004) .

The fourth wave was religious. Islam tolerated all exaggerations in religious extremism. This began at the time of the 1979 Iranian revolution - although the leader of the revolution was an exile in France, America's ally, and was flown by a French plane to Tehran (David, Rapoport, 2004) and the Soviet invasion of Afghanistan. America with the help of the Arab countries in confronting the Soviet Union through the Arab Mujahideen, supported by American weapons and Arabs with money and youth, and the Mujahideen's instead of liberation of occupied Palestine became the liberation of Afghanistan more interest, this was goal itself.

Cronine found that the majority of $90 \%$ of terrorist organizations did not exceed the age of 1-2 years, and those who managed to cross that threshold. The main reasons for the disappearance of terrorist organizations were: (1) arresting or killing the leader; (2) failure to transition to the next generations ; (3) achievement of the group's aims ; (4) the transition to a legitimate political process, (5) the loss of popular support, (6) repression, (7) the transition from terrorism to other forms of violence, and it is clear that there are Organizations that have managed to survive well after the wave of terrorism that has taken place in the world, and among these religiously motivated organizations that indicate the strength and continuity of the For religious motives.(Cronin,Audrey Kurth ,2006) In our view, religious beliefs serve as a cover for some states with interests in the Arab region, such as America and Israel, to keep the region politically, socially and economically unstable. So that its people do not enjoy their wealth like the rest of the peoples in the world. After al-Qaeda and various organizations all contributed to the destruction of Syria and Iraq, which are an important Arab force, it is an interest for USA and Israel.

\section{2: Motives of terrorism in the Arab region :}

The causes and motives of the emergence of terrorism in the Arab region are two types: one public and the other private.

\section{2 : 1 : Public motivation:}

\section{2: 1: 1: The failure of the modern Arab state :}

The failure of the Arab state came as an inevitable result of the division of the Arab world to several states by colonial states. The Arab state appeared as fragile and weak after the division of colonialism. This was purely the goal of colonialist.to left behind it needs it after independence and the most important specifications unable to protect themselves. And the colonial state strengthened the distrust between the regimes of these countries, in addition to developing the spirit of separations among them through the border problems that it set, which reflected on the performance of the state - although some of them possessed enormous wealth - and this appeared on the political, economic and social life, The state has not changed the way of life, and has not reached the Arab citizen in many countries to the stage of well-being, and remained a weak state looted by corruption as a result of the strengthening of social class and class exploitation, and the inability to protect itself from external dangers, the state that colonized told it that danger comes from Arab neighbors In order to remain in its orbit(Ebrahim , Saa'd Adean ,1998), and this is in the interest of Israel as a result of the permanent division, and the interest of America to make alliances 
with them and the sale of weapons to these countries, in spite of the American-Israeli alliance organic, and therefore the result of this is achieving the goals of them .

\section{2: 1: $2:$ The tyranny of the Arab state:}

The inability of the Arab state and its weakness led to the use of tools of coercion against its opponents and pressure on its citizens. The Arab state did not think of developing its internal policy to achieve true democracy. and to be the state of law and institutions. It exploited the calm available from the Arab street and maintained the traditional political system governing by using the force. Without the legitimacy, and despite the changes that have taken place in the world after the breakup of the Soviet Union in the final decade of the last century remained the same, exceeded the right human of the Arabs in freedom and dignity and political participation, and thought the Arab state that the changes that occurred To the world that it is outside its space, and as a result of the evolution of the means of global communication and the emergence of social media has been the emergence of groups using violence and terrorism, to gain the citizens and their support and to shake the image of the Arab political systems, (William, Zargen, 1988 ) and because the revolutions of the Arab Spring has preceded Without the leadership or clear project, this gave the terrorist groups the opportunity to exploit the chaos in order to get the authority, the result was the infiltration of terrorism in those countries and participating with the Arab revolutions, the result is failure of the Arab Spring and the success of terrorism .

\section{$2: 1: 3:$ The role of the Arab state in the interests of major powers.}

The Arab state relinquished much of its foreign sovereignty and part of its internal sovereignty because of its weakness. It remained closely linked to the state it colonized. It was used after independence to achieve the goals and interests of the major powers. This does not mean joining the alliances of these powers but in order to preserve its regime. The Arab political regimes, without exception, maintained the weakness of the state and the lack of development to dispense with colonial powers in most areas. It is true that the Arab state has developed in the field of public services, but it has been delayed in many. Despite its wealth, And despite the wealth imported weapons only to protect their systems from the people, did they think that the manufacture of weapons and export to abroad, such as Israel, for example?, There is no Arab country that makes a single gun to be issued out, let alone heavy weapons!, Most of which relied on energy sources and remained hostage to this wealth and did not develop its economy despite the existence of scientific capabilities and brains, which were exported abroad, this policy made them hostage to the great powers and the willingness to play any role assigned by these forces on the one hand (Khaldoun, .H.Annageeb, 1987).

On the other hand, the state has been embroiled in major conflicts that it does not serve. In the 1980s, the Soviet Union occupied Afghanistan because of the overthrow of communist rule, fearing the arrival of the Soviet Union oil resources and warm water, then America decided to confront Soviet Union through Arab countries under the pretext of the occupation of a Muslim country by communism - in spite of Palestine was occupied since 1948 - All the Arab regimes, without exception, participated in encouraging the youth in this jihad. Some of them participated in the financial support, provided them with money and weapons, and opened training camps in Afghanistan. The war was by proxy and in the name of the Jihad that was overthrown by the Organization of the Islamic Conference in 1991 in Dakar (Benhada, Tareg, 2019).

After the withdrawal of the Soviet Union as a result of its internal status, most of the young mujahidin returned to their Arab countries, turning hostility from the Soviet Union to America and the regimes of the Arab countries and spread terrorism in a different way against the allies of yesterday, the major powers and Israel exploited the bombings of New York and Washington on September 11, 2001, to start war On terrorism, starting with the occupation of Afghanistan in November 2001, and the occupation and destruction of Iraq on 9/4/2003 on charges of the Iraqi regime's relationship with al-Qaeda and its possession of weapons of mass destruction. (Al-Jamra, Younes ,2009 ) Thus Israel ensured its safety from the conflict and America controlled the energy sources and the entire region.

\section{2: 1: 4 : Palestine Issue}

After the occupation of $78 \%$ of Palestine in 1948 and the failure of the Arab armies to save it Israel announced the establishment of the State in the same year, the Arab-Israeli conflict continued to the war of June 1967, where the rest of Palestine - the West Bank and East Jerusalem and Gaza strip - fell into the 
hands of the Israeli occupation, in addition the Arab lands like the entire Sinai desert of Egypt, and the entire Golan Heights from Syria, To the war of October 1973, as the war was not for liberation occupied lands, but was for negotiations, especially after the cessation of supplying the West with Arab oil, The Arab-Israeli conflict turned into a Palestinian-Israeli conflict. The 1974 Rabat Arab Summit recognized that the Palestine Liberation Organization was the sole legitimate representative of the Palestinian people. Therefore, the burden of liberation was placed on the shoulders of the PLO, which exited Jordan by force in 1970 to southern Lebanon, In that period, the Egyptian-Israeli negotiations began and ended with the signing of the Camp David Treaty in 1979 and the return of the entire Sinai Peninsula to Egypt. and the Egyptian position cancelled the results of the Khartoum summit in 1967 : no peace, no surrender, no negotiations with Israel(Heikal ,Mohamed Hassnein,1998).

In 1982, Israel launched a war against southern Lebanon, and the PLO went to Tunisia. During that period, the Iraqi-Iranian war was over and over. But Iraq stopped exporting the Iranian revolution. The Gulf states supported Iraq with money and weapons. During that period, the Palestinian Intifada began in the occupied territories. The Iraqi-Kuwaiti dispute ended by the occupation of Kuwait on August 2, 1990, followed by the war of liberation of Kuwait in the 1991 of America led by the United States and thirty countries participated in it. As a result of the war in addition to the liberation of Kuwait, USA sponsored peace conference On 30 October 1991 in Madrid, The conference was held in the presence of all the Arab parties, including Israel and the Palestinians, with the Jordanian delegation. The conference was depending on instead the Land for Peace Conference and UN Resolutions 242 and 338, One of the outcomes of the conference was the signing of the Oslo Declaration of Principles between Israel and the Palestine Liberation Organization on 13 September 1993, the postponement of the Jerusalem and refugee issue to the final agreement, and Jordan's signing of the Wadi Araba Treaty in 1994 (Heikal, Mohamed Hassnein,1998) .

In fact, there is a dispute between the official and the popular, regardless of the treaties between the Arab regimes including the Palestinians, the Arab system recognizes that Israel has become a reality, but the Arab peoples does not recognize the existence of Israel and considers it occupied Arab land has its sanctity , and it has legitimate owners (Palestinians ), And therefore considers an Issue of Palestine the key to calm in the region, and other will remain as America and Israel are messing around in the region, and use its tools in the region to protect Israel and preserve its interests.

\section{$2: 2:$ The privet motivations of terrorism :}

\section{$2: 2: 1$ : The spread of extremis religious thought among young people.}

In fact, the emergence of extremist religious movements began and spread among the youth. The idea was to establish an Islamic rule for the caliphate and unify the Arabs and Muslims by force in order to liberate the Muslim countries, foremost of which was the liberation of historic Palestine. But the withdrawal of the Soviet Union put an end to this, They were not absorbed by the Arab political regimes and began to inculcate them in prisons, the same regimes that encouraged them to fight in Afghanistan (Abdel-Qader Hermassi, Mohamed ,1987).

When the revolutions of the Arab Spring began to spread in the Arab countries, it began to be challenged by those who claim to be the champion of democracy America, Israel, and the West and some of the East, because these revolutions are not in their interest. The emergence of religious streams splintering from alQaeda such as Dahesh and, Annosrah group and many who appeared in the Syrian and Iraqi arena, And supported the United States and Israel some of these organizations to achieve their goals in the destruction of Syria and exhaustion of Iraq for a final, and some oil countries and provided money and weapons under the supervision of America and Israel and facilitated other countries to enter Syria and Iraq, was all the vandalism is the goal of the US and Israeli and Western categorically.

\section{2: 2: 2: Poverty .}

America and its allies have exploited all the tools available to all terrorist organizations with the aim of sabotaging the region and their economies and turning them back so that the peoples of the Arab East will be suffocated. Poverty and hunger will spread to the same situation : Namely, Israel's strong control over its surroundings and the imposition of final solutions that are appropriate for the Arabs and Palestinians who have the cause (Bahoumah, Mohamed, 2014), And the so-called deal Century, whose features are 
published in the media, and some researchers believe that America has carried out some of the steps that are believed to be part of the deal: The first is that Jerusalem should be the united and eternal capital of the State of Israel, and secondly, that the United States should not pay the dues of the UN Relief and Works Agency, which was issued by UN Resolution 302 at the fourth session of the General Assembly on 8 December 1949,( UNRWA.Org, 2019)until the return of the refugees, 194, issued a year ago on December 11, 1948, (UNRWA.Org, 2019) and American behavior came in order to eliminate the right of return of Palestinian refugees to their homes.

This situation, made by force by the major powers in favor of Israel and the weakness of the Arab nation, has made it a provocative situation for Arab and Muslim youth, an indication that the Issue of Palestine is the key to war and peace and all terrorism in the region.

\section{2: 2: 3 : Unemployment among young people.}

The Arab world is one of the most youthful regions in the world, comprising 32\% of the population of 22 countries between the ages of 15 and 29.(Lancaster,Pat, 2009) This is not a small percentage in modern societies (32\%).( Masrawy.com,2019) Youth are therefore vulnerable to blackmail and out of the traditional social pattern, which poses a threat to their countries and political systems that have not been given to them to pursue the search for a way out (Masrawy.com, 2019).

Therefore, they are vulnerable to religious extremism and to confront their regimes. They have been exploited by money and influence. They have been the fuel of terrorism. They are the tools of many terrorist organizations, which are also one of the great powers. Many of them were suddenly condemned as devils and began implementing the new world order. Without thinking about who is the damage? And in the interest of what they do? .

\section{3 : American and Israeli targets in the region : \\ $3: 1$ : Maintaining the security of Israel.}

American politicians believed in biblical texts that gave promises that the State of Israel borders from the Nile to the Euphrates, and the embodiment of that Israeli flag has two lines in blue and a Star of David on a white cloth. The upper line represents the Nile River and the lower line is the Euphrates River and between them the land of Israel, which the Lord granted to The descendants of Abraham peace be upon him(ALHazaima, Mohamed Awad , 2005), And for the faith of the American politicians under the pressure of the Zionist lobby in the United States of America, for their faith in the biblical doctrine that provides for those promises of God, their priorities when the inauguration of any President in the White House to protect Israel and maintain the factors that provide security, and therefore came agreements with some Arab countries to protect The security of Israel, followed by the occupation of Iraq in 2003 destroyed its regime and dismantled its army, Iraq became a scene of terrorism, which moved from Afghanistan in a smooth way to resist America (Al-Jamra, Younes,2009).

The United States took advantage of the situation in Syria in 2011 when the events began, and entered through Iraq, and was watching the situation with little intervention but rare, and left the situation to the Russian Federation and the movements of some terrorist organizations, as if watching an electronic game is destroyed everything, The Syrian power to intervene in terrorism, all for the benefit of Israel and its security.

\section{3 : 2 : weaken the Arabs world around Israel .}

America's policy is based on the importance of Israel's military role in the region. It is an important and dedicated military force. This force can be used when necessary. It also poses a permanent threat to its neighbors. Shahak, the former Israeli defense minister, said that Israel and its army is an American investment. It is difficult to lose it or lost this investment, his continued : "It is the Israeli force that makes America care about Israel and close its eyes to its violations and evils at home and abroad." This force is influential in American pro-Israel policy, not the Jewish lobby within the United States only"( Al-Jamra, Younes,2009, P.131).

The Arab situation is now unstable, exhausted by the armed conflict inside it, from Syria to Iraq, Yemen and Libya, and the Arab situation continues towards weakness, dispersion and disintegration around Israel, in 
addition to doctrinal and sectarian conflict at the political level in countries, and armed fighting in other countries, and this Provides security and stability to Israel.

\section{3 : 3 : Resolve the Arab-Israeli conflict according to the American-Israeli vision .}

Biblical doctrine plays a role in American religious life. From this perspective, American foreign policy sees that the Israeli state embodies the historical and religious heritage of the American people. It is not surprising that we say that American aid to Israel is to satisfying God (Al-Moghrabi, Fouad , 2002), Therefore, America with its various projects and tools seeks to secure the State of Israel and pressure the Arabs by all means to resolve the Arab-Israeli conflict in the way it believes it maintains Israel's security. When negotiations started and some agreements were signed, Israel began to dodge negotiations based on the American presence in the region and using its different tools (Zreik, Abdol Qadir,2005), This requires the provocation of sectarian strife and blindness to terrorist organizations in order to intervene in the region and to weaken it. Thus, the final solution to the Arab-Israeli conflict will be imposed according to Israel's wishes. Therefore, the armed conflicts of the various terrorist organizations and equipped with all the necessary weapons to destroy the Arab Orient Is an Israeli-American goal.

\section{3: 4 : Control of energy sources in the region}

The oil crisis that entered the political arena in the October 1973 war raised the value of oil by banning the sale of oil to the United States. Since then, American policy has believed that oil must be separated from the Arab-Israeli conflict in the region, With the decline of the American need for Arab oil, followed by the second oil crisis in 1979 that accompanied the Iranian revolution, America saw that this affects the US economy negatively, and therefore the US military force stationed in the region will not hesitate to intervene militarily against any country in the region is trying to prevent The flow of oil to consuming countries, The first intervention indirectly supported jihadist movements against the occupation of Afghanistan by the Soviet Union and its attempt to access energy sources.( Moheisn , Manar , 2019) As the United States' need for Arab oil declined, it sought to control it for its continued flow into world markets, especially US oil companies , And the aim is that the suspension of oil hurts the economy of America and the global economy.

\section{3: 5 : USA presence in the region to deter Iran.}

After the cessation of the Cold War between the Warsaw alliance and the Atlantic Alliance, America's policy depended on creation an external enemy, which was the Soviet Union- Thus, the American foreign policy adopted- With the end of the Eastern camp and with its leader Soviet Union ,the search for an alternative began, Islam was the first alternative , By creating organized terrorist groups, the United States believes that these groups establish their presence in the region and control them, and to maintain balance among these groups without winning one and ending only with the end of the goal, as well as maintaining the military and political balance between Iran as a Shiite state and the Sunni Gulf states, Each of these parties seeks to be a regional player in the Middle East region, and this affects the balance of military power in the region, which may harm Israel as it exists in the region (Moheisn, Manar, 2019), Which means that what we see from the conflict between the doctrines and Islamic groups is within the balance set by the United States, because each of these players, headed by America accused of terrorism, Iran is accused through the popular mobilization in Iraq and the Quds Force in Syria, and a America through its conflict with Sunni groups in Iraq and Syria, not to mention what is happening in Yemen. Although US military power can destroy Sunni terrorist groups seeking to establish a caliphate, they use it to impose control over the region for many reasons.

\section{4: Conclusions:}

After answering the pivotal question and the questions that came out of it, the study reached the following results:

*The concept of terrorism is not clear, and there is no specific or agreed definition by researchers, states and international organizations.

*America and Israel have goals in the region, and seek to weaken the region and dismantle, by provoking sedition and sectarian and ethnic wars, and they use the terrorist organizations to ensure America's survival in the region and to protect the security of Israel, and to control the region resources of the oil . 
*There are four Importance issues in the region that form the basis of America and Israeli blackmail to the region itself :

1 - The Palestinian issue. This issue is considered the key to war and peace in the region. The peoples of the region are not satisfied with America because of its clear inclination towards Israel. Therefore, this issue is the main driver of youth and peoples of the region.

2 - The Israeli presence: Many decisions have been issued against Israel from United Nations bodies, international committees and conferences. Israel has not considered any decision because of American support, in addition to Israel's possession of nuclear power and long-range missiles, knowing that others in the region are forbidden to do so, States have been occupying and overthrowing political regimes for this, and this poses a threat to the region and a provocation to the peoples and youth of the region .

3- The importance of the geographic location of the Arab region. Arab geography forms the confluence of ancient continents: Europe, Africa and Asia, the heart of these continents, and therefore who controls this region controls the world, and the region has the world's largest energy reserves .

4- Finally , America has a goal that its military presence in the region means a threat to Iran which threat Israel .

\section{5 : References :}

[1] Abdol Haleem ,Amera : ( 2009), Cairo, January 1, http://www.digitalahram.org.2og/articales.aspx?serial=96317\&eid=121, date13/1/2019.

[2] Abdel-Qader Hermassi , Mohamed :(1987), Youth and politicization of religion, Tunisia case study, paper presented to the Arab Youth Symposium in Rabat, 20-22 / 10/1987.

[3] Al-Hazaima , Mohamed Awad,: (2005)International Issues, problems of century gone and century coming .

[4] Aljamra ,Younes : (2009), The Ideological Vision 2001 - 2008: The Second Generation of Neoconservatives in American Policy Towards the Arab Orient, Irbid - Jordan, The East International Center for Studies, First Edition.

[5] Al-Moghrabi , Fouad : (2002 ) US Foreign Policy and the Palestinian Cause, Abu Al Ghad Institute, Bir Zeit, Palestine.

[6] Al-Mukhadmy, Abdul Qadir Zreik: (2005), The Greater Middle East Project: Facts, Objectives and Implications, Arab Science House, Beirut .

[7] Al-najjar , Wa'am Mahmud :(2012),The Political Recruitment of Terrorism in American Foreign Policy after September 11, 2001, and the Study of an Unpublished Master Thesis .

[8] Annageeb, Khaldun .H. : ( 1987), Society and State in the Gulf and the Arabian Peninsula: From a Different Perspective, Beirut, Center for Arab Unity Studies, First Edition.

[9] Attia, Ahmad : (1968), The Political Dictionary, Cairo, Dar Al-Nahda Al Arabiya, Third Edition.

[10] Awad,Hani : Terrorism .... The life cycle of the concept http://www.ultrasawt.com 20/11/2015 .

[11] Barhoumah ,Mohamed : ( June ,2014 ) Factors of the Rise of Jihadist Salafism in the Levant, Journal of International Politics, No. 177.

[12] Benehda ,Tareg: http://www.m.hespress.com ,21/1/2019 .

[13] Cronin, Audrey Kurth : (2006), How al-Qaida Ends: The Decline and Demise of Terrorist Groups. - International Security, 1/2006.

[14] David C. Rapoport : ( 2004 ), Four Waves of Modern Terrorism. - Attacking Terrorism:Elements of a Grand Strategy. Audrey Kurth Cronin, James M. Ludes (eds.). Washington DC: Georgetown University Press.

[15] Ebrahim, Saa'd Adean : (1998), Society and state in the Arab world ,Beirut, Center for Arab Unity Studies, Edition 1.

[16] Geneva Convention, (1937), Article 1, Terrorism in International Covenants.

http://www.altayar-consultants,com/studyaspex?id=64language=en 13/1/2019 .- Gregor ,Bruce : (2013), Definition of terrorism , social and political effects , journal of military and veternas , health, volume21, number 2 : May.

[17] Hawari ,Adel and Mosleh, Saa'd : ( 1999 ), Encyclopedia of Social Sciences, Transfer to the Arab : Hawari ,Adel and Mosleh, Saa'd, Dar al-Maarifa University. http://findarticles.com/p/articles/mi_m1510/is_n60/ai_6641070>, (accessed on 15July 2007. 
[18] Heikal, Mohamed Hassaneinl: (1998) ,Future Concerns, The Arab Future Journal, Beirut, Center for Arab Unity Studies, No. 108, February. http://www.masrawy.com 9/2/2019. http://www.UNRWA.org, date 9/2/2019 . http: // www.arz.m.wikipedia.org ,31/1/2019

[19] Joel Shurkin : (1998), Robust Terrorism. - Whole Earth Review. Fall.

[20] Lancaster,Pat ( July 2009 ), “ youth the great 21st-century challenge “, Middle East (402).

[21] Moheisen ,Manar : US Interests in the Middle East: Reality and Image , 26 /1 /2019 . http://www.arabi21.com/story/908040.

[22] Walter Laqueur : ( 1977) Terrorism, London, Weidenfeld and Nichol son .

[23] William, Zargan : (1998) ,The Opposition as a Support for the State, The Future of the Arab Magazine, Beirut, Center for Arab Unity Studies, No. 10 8, February . 